\title{
Immunological vulnerability and adjustments to environmental thermal variability
}

\author{
Variabilidad inmunológica y ajustes a la variabilidad térmica ambiental
}

\author{
FRANCISCO BOZINOVIC ${ }^{1,2, *}$, TAMARA P. CATALÁN ${ }^{1,2} \&$ ALEXIS M. KALERGIS $^{2,3}$ \\ ${ }^{1}$ Departamento de Ecología and LINCGlobal, Facultad de Ciencias Biológicas, Universidad Católica de Chile, \\ Santiago 6513677, Chile \\ ${ }^{2}$ Millennium Institute on Immunology and Immunotherapy, Universidad Católica de Chile, Santiago, Chile \\ ${ }^{3}$ Departamento de Genética Molecular y Microbiología, Facultad de Ciencias Biológicas and Departamento de Reumatología, \\ Facultad de Medicina, Universidad Católica de Chile, Santiago 6513677, Chile \\ ${ }^{*}$ Corresponding author: fbozinovic@bio.puc.cl
}

\begin{abstract}
Ecological physiologists recognize the potential impacts of temperature on physiological traits, however less attention has been paid to changes in thermal variation on a scale that pertains directly to living organisms. Also, few studies have examined the effects of temperature variation or other climatic drivers on host-pathogen interactions. We evaluated the effect of acclimation to ambient temperature variability $\left(0,4\right.$ and $8{ }^{\circ} \mathrm{C}$ daily variability) on the immune performance in the insect Tenebrio molitor (Coleoptera). We observed that antibacterial activity differed significantly between treatments. In addition, variances of antibacterial activity were larger under the more variable thermal conditions. Similarly to antibacterial responses, tyrosinase phenoloxidase activity was higher in animals living in the most variable thermal condition. We hypothesized that a stress-associated mechanism may affect negatively the constitutive immune activity in T. molitor. It is well known that acute stress can cause in insects a transient impairment in the resistance to bacterial infection. This increase in susceptibility to diseases is mediated, at least in part, by the release of neuro-hormones in response to stress.
\end{abstract}

Key words: ecoimmunology, immune performance, mealworm beetles, temperature, tyrosinase phenoloxidase.

\section{RESUMEN}

Si bien los ecofisiólogos reconocen el impacto de la temperatura sobre los atributos fisiológicos, se ha prestado poca atención a la variación térmica a escalas que afectan directamente a los organismos. Además, son pocos los estudios que han examinado el efecto de la variabilidad térmica y otros factores climáticos en las interacciones patógenohospedero. Evaluamos el efecto de la aclimatación a la variabilidad térmica ambiental $\left(0,4\right.$ and $8{ }^{\circ} \mathrm{C}$ variabilidad diaria) sobre la respuesta inmune en el insecto Tenebrio molitor (Coleoptera). Observamos que la actividad antibacteriana difiere significativamente entre tratamientos térmicos. Además, las varianzas en la actividad antibacteriana fueron mayores bajos las condiciones de mayor variabilidad térmica. Del mismo modo que las respuestas antibacterianas, la actividad de tirosinasa fenoloxidasa fue mayor en los animales viviendo bajo las condiciones térmicas más variables. Hipotetizamos que los mecanismos de estrés asociados podrían afectar negativamente la respuesta inmune constitutiva en T. molitor. Se conoce que el estrés agudo causa en insectos una discapacidad transiente en la resistencia a la infección bacteriana. Este aumento en susceptibilidad es mediado, al menos en parte, por la liberación de neurohormonas en respuesta al estrés.

Palabras clave: ecoinmunología, gusano de la harina, rendimiento inmune, temperatura, tirosinasa fenoloxidasa.

\section{INTRODUCTION}

Studies of genetic differences and phenotypic plasticity in physiology among species and populations, and of the physiological changes that organisms display when temperatures or other climatic factors change, may help us to answer several evolutionary questions
(Futuyma 1998). Regarding adaptation to environmental variability (e.g., temperature), theoretically it will depends on the temporal pattern of environmental changes and the tolerance of each phenotype.

Most studies relative to the effects of thermal variation have focused on life-history traits (e.g., Dallwitz 1984, Ragland \& Kingsolver 
2008, Ji et al. 2007, Pétavy et al. 2004, Folguera et al. 2009). Along these lines, Lamb (1961) suggested that fluctuating temperatures have a distinct effect on insect development as compared to constant temperatures (see also Dallwits 1984, Hilbeck \& Kennedy 1998, Hercus et al. 2003). Recently, studies assessed the impact of mean temperature and thermal variance on physiological performances in ectotherms (Terblanche et al. 2010, Folguera et al. 2011, Bozinovic et al. 2011a, 2011b). In an overwintering butterfly, Williams et al. (2012) reported that ambient thermal variability increases the effect of autumn warming and drives metabolic rate depression. In addition, climate may alter the frequency of potentially pathogenic microbial organisms, which can cause new diseases to various species and populations (Arias et al. 2011). Indeed, Paaijmans et al. (2010) showed that daily fluctuations in temperature influence malaria infection, development and transmission. Indeed, climate change may have an important effect on infectious diseases by influencing both the parasite and the host (Epstein et al. 1998, Patz et al. 2005, Tabachnick 2010, Rohr et al. 2011). In addition Krams et al. (2011) demonstrated in water striders that body size is the main trait linking overwinter survival and resistance against infections. In mealworms beetles Krams et al. (2013) also demonstrated a trade-off between cellular immunity and life span. Although some predictive models have suggested that climatic variability will influence infectious disease transmission dynamics, the immunological responses behind - at scales pertinent to individuals - oriented to understand their degree, spread and coverage are uncertain and remain still very descriptive (Mandrioli 2012). In this perspective, the field of ecological immunology will help to explain and predict how immune defenses have evolved in a changing world and under variant habitat conditions, to sustain host fitness (Demas \& Nelson 2011, SchmidtHempel 2011). Further, studies in this area will allow characterizing the range of phenotypic traits of native and allien species relative to the immune barriers to microbial aggression. Up to this date, few studies have examined the effects of temperature variation or other climatic drivers on host-pathogen interactions in current host and pathogen populations (but see Raffel et al. 2013, Krams et al. 2011). Here we evaluated the effect of experimental changes in ambient temperature variability on the immune performance in the mealworm beetle Tenebrio molitor (Coleoptera: Tenebrionidae; Linnaeus 1758) which is used here as a model species. Direct research examining alterations in host immune function in native as well as invasive species are needed to understand the potential effect of temperature variation on pathogen resistance and diseases, even on human populations. Based on the relationship between environmental temperature and physiological performance (Angilletta 2009), we propose that if the mean environmental variables are below the physiological optimum, brief warming, will enhance the immune response more than brief cooling impairs performance (Lean \& Rind 2008, Rahmstorf \& Coumou 2011). Here, we have used tyrosinase phenoloxidase (PO) quantity and antibacterial activity measured as antimicrobial protein production as indicators of an insect's immune defense. Because PO is considered the key enzyme for encapsulation, melanization and wound repair (Söderhäll \& Cerenius 1998, Sugumaran 2002), this enzyme is critical as an insect defensive strategy. Further, antibacterial activity represents the action of humoral defense including lysozyme activity, which is critical for the degradation of bacterial cell walls (Schneider 1985). Thus, these systems provide an efficient defense against pathogens and parasites (Siva-Jothy et al. 2005). Insects present an immune system endowed with only innate immune components consisting of cellular (ocytosis and encapsulation) and humoral factors (antimicrobial peptides (AMPs) and the components of the pro-phenoloxidase pro-PO. Further, larvae were used because at this stage they are extremely sensitive to environmental conditions (Min et al. 2006, Morales-Ramos et al. 2010, Urrejola et al. 2011). We acclimated T. molitor larvae to different combinations of temperature variability and compared the vulnerability and responses of two of their constitutive immune traits to such experimental climate extremes and variability of temperature (but see also Arias et al. 2011 for trade-offs among ontogenetic states). 


\section{METHODS}

\section{Mealworm cultures}

Larvae of $T$. molitor were randomly selected from a stock culture maintained since the year 2000 under laboratory conditions $\left(23 \pm 2{ }^{\circ} \mathrm{C}(\mathrm{SD})\right.$ and $12: 12$ photoperiod) and fed with a mixture of flour $(60 \%)$, oats $(20 \%)$, yeast (10 \%) and bran (10\%), and apples ad libitum. Insects were kept in plastic containers carefully cleaned and autoclaved, mixed dry food was heated at $70^{\circ} \mathrm{C}$ for 72 $\mathrm{h}$ to eliminate pathogens and parasites. 30 larvae with similar body mass (ca. $0.16 \pm 0.03 \mathrm{~g}$ (SD)) were used for the experiments and different sets of animals were used for each measurement to avoid any effect of previous manipulations on the data obtained. Animals included in the experiments showed no signs of moulting.

\section{Acclimation to temperature variability}

Individuals were randomly assigned to one of three thermal treatments in climatic chambers according to our previous protocols (see Bozinovic et al. 2011a, 2013, Folguera et al. 2009). In one of the treatments temperature was maintained at $20{ }^{\circ} \mathrm{C}(\delta=0, \delta 0$ group) or constant temperature regime. In the other two treatments, temperature varied during the day, reaching a maximum during the period of light and a minimum during the night (alternating temperature regimes): $28-12{ }^{\circ} \mathrm{C}(\delta=8, \delta 8$ group $)$ and $24-16{ }^{\circ} \mathrm{C}(\delta=$ $4, \delta 4$ group), in all cases diurnal temperature is given first. These thermal scenarios represent predictions of climate change for central Chile according to http:// www.dgf.uchile.cl/PRECIS/\#Escenarios_Climaticos. Specimens were fed ad libitum during all experimental time. At the end of the acclimation period (3 weeks, sensu Catalán et al., 2011) and to test for the effect of our thermal treatments on immune response we measured two haemolymph immune variables in individual larvae, namely: antibacterial activity and haemolymph phenoloxidase (PO) activity. We used ten individuals per treatment.

\section{Immune traits}

To measure antibacterial activity, haemolymph (5 $\mathrm{mL}$ ) was obtained with a Hamilton syringe and diluted with $24 \mathrm{~mL}$ PBS, and $1 \mathrm{~mL}$ of an overnight culture (approximately $2.5 * 10^{6} \mathrm{CFU} \mathrm{ml}^{-1}$ ) of streptomycinresistant Micrococcus luteus was added to the solution. The mixture was incubated at $30{ }^{\circ} \mathrm{C}$ with agitation at $150 \mathrm{rpm}$ for $1 \mathrm{~h}$. Then, the mixture was diluted 100 times and plated on LB agar containing $5 \mathrm{mg}$ $\mathrm{ml}^{-1}$ streptomycin (Sigma S6501). The mixture (50 and $100 \mathrm{ml}$ ) was spread onto two plates for each animal. Plates were incubated at $30{ }^{\circ} \mathrm{C}$ for $48 \mathrm{~h}$. The number of colonies was counted on each plate and the mean number of colony-forming units (CFU) per $\mathrm{ml}$ of mixture spread on the two plates was used to calculate the antibacterial activity as the percentage of dead bacteria relative to control plates without larval haemolymph (Catalán et al. 2011, 2012).

On the other hand, to measure PO activity, haemolymph $(5 \mathrm{~mL})$ was added to $200 \mathrm{ml}$ of ice-cold PBS at $\mathrm{pH} 6.4$ in an Eppendorf tube and vortexed. Samples were frozen at $-80{ }^{\circ} \mathrm{C}$ until use. $\mathrm{PO}$ activity was assayed spectrophotometrically with L-Dopa as substrate. L-Dopa (Sigma D9628, $100 \mathrm{~mL}, 20 \mathrm{mM}$ ) was added to $100 \mathrm{~mL}$ buffered haemolymph and the OD $(492 \mathrm{~nm})$ of the mixture was determined at $25{ }^{\circ} \mathrm{C}$ with a microplate reader (Packard Bioscience model AS 10001) at $10 \mathrm{~min}$ intervals during $90 \mathrm{~min}$. Enzyme activity, expressed as PO units per ml haemolymph, was obtained as described in Catalán et al. (2012).

\section{Statistical analyses}

The effects of thermal variability on antibacterial and phenoloxidase activities were tested using an ANOVA test with fixed factor (acclimation temperature variability: $\mathrm{d} 0, \mathrm{~d} 4$ and $\mathrm{d} 8$ ). Antibacterial activity and phenoloxidase activity data were transformed

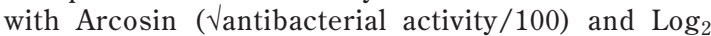
(phenoloxidase activity), respectively to meet assumptions, and covariance between body mass and all traits was tested. All data were tested for normality and homoscedasticity with Kolmogorov-Smirnov and Levene tests. When differences were significant at $\mathrm{P}<0.05$ after the general linear model tests, a posteriori Tukey HSD test for multiple comparisons were used. All statistical analyses were conducted using Statistica 6.0 software (Statsoft Inc., Tulsa, OK). Values are expressed as arithmetic mean $\pm 1 \mathrm{SD}$.

\section{RESULTS}

Antibacterial activity differed significantly between different thermal treatments (ANOVA: $\left.\mathrm{F}_{2,27}=3.67, \mathrm{P}=0.039\right)$. Antibacterial activity was higher at a constant thermal condition (d 0$)$ than it was at the highest thermal variability $(\mathrm{d}$ 8) (Tukey HSD: d0/d8: $\mathrm{P}=0.032$ ). No statistical differences either between $\mathrm{d} 0$ and $\mathrm{d} 4$ (Tukey HSD: $\mathrm{d} 0 / \mathrm{d} 4: \mathrm{P}=0.226$ ) or between $\mathrm{d} 4$ and $\mathrm{d} 8$ (Tukey HSD: $\mathrm{P}=0.592$ ) (Fig. 1) were observed. In addition, variances of antibacterial activity were larger under the more variable thermal conditions ( $\mathrm{d} 4$ and $\mathrm{d} 8$ ) than the observed at a constant temperature. Under constant temperature conditions, antibacterial activity ranged from 60.8 to $83.6 \%, \mathrm{SD}=0.072$. At the $\mathrm{d} 4$ thermal treatment antibacterial activity varied from 32.3 to $88.7 \%, \mathrm{SD}=0.170$. Finally at $\mathrm{d} 8$ thermal acclimation, antibacterial activity ranged from 2.8 to $65.5 \%, \mathrm{SD}=0.211$.

Similarly to antibacterial response, PO activity differed significantly among treatments (ANOVA: $\mathrm{F}_{2,27}=3.65, \mathrm{P}=0.040$ ). However, the higher enzymatic activity was recorded in animals living in the most variable (d8) thermal condition. The a posteriori test showed statistical differences with the intermediary variability thermal condition (Tukey HSD: d4/d8: $P=0.031$ ) (Fig. 2). Finally, standard deviations did not show any pattern being 1.83 , 1.93 and 1.14 for $\mathrm{d} 0, \mathrm{~d} 4$ and $\mathrm{d} 8$ treatments, respectively. 


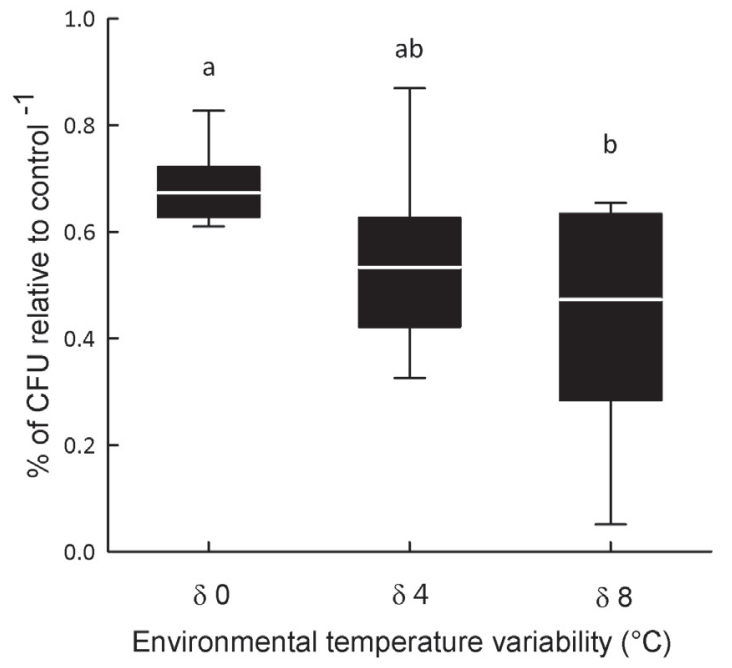

Fig. 1: Statistical values of antibacterial activity at different thermal treatments. The \% of colony-forming units (CFU) relative to the control group is indicated. The boundary of the box closest to zero indicates the 25th percentile, a line within the box marks the median and the boundary of the box farthest from zero indicates the 75th percentile. Whiskers (error bars) above and below the box indicate the 90th and 10th percentiles, respectively. Similar letters indicate differences that are not statistically significant between thermal treatments. Control is haemolymph free.

Valores estadísticos de actividad antibacteriana a diferentes tratamientos térmicos. Se indica el \% de unidades formadoras de colonias (CFU) en relación al control. El límite de la caja cercana a cero indica el percentil 25 , la línea dentro de la caja marca la mediana y los límites de la caja alejada de cero marcan el percentil 25. Las barras de error sobre y bajo la caja indican los percentiles 90 y 10. Las letras similares indican diferencias que no son estadísticamente diferentes entre los tratamientos térmicos. El control es sin hemolinfa.

\section{DISCUSSION}

The impact of increased frequency of extreme thermal events on diseases and immunological responses remains unknown (Burroughs 2007). Although epidemiological studies have established relationships between climate variability (e.g. El Niño Southern Oscillation or ENSO) and outbreaks of infectious diseases, the mechanisms responsible for these interactions remains elusive (Checkley et al. 2000). Our data suggest that thermal variability may modify host resistance and immunological response performance, and can lead to changes in the physiology of host-pathogen interactions. The most likely ecological consequences are

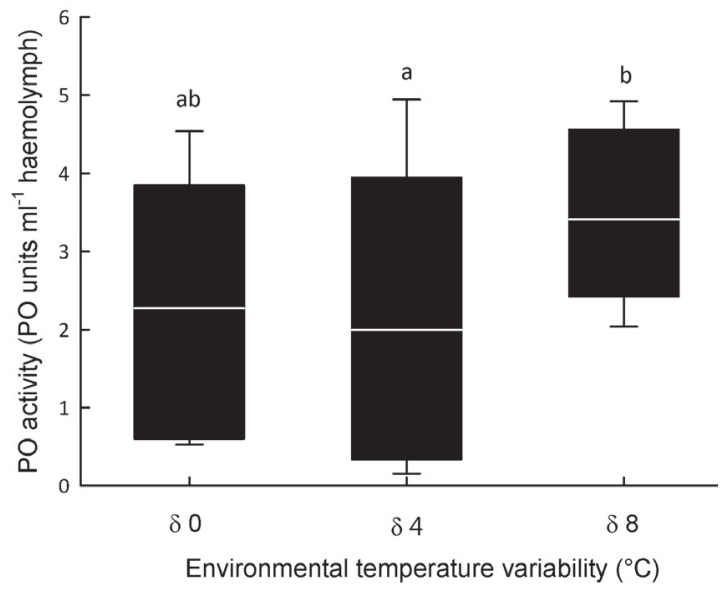

Fig. 2: Data are shown as box plots representing statistical values of tyrosinase phenoloxidase $(\mathrm{PO})$ activity at different thermal treatments. The boundary of the box closest to zero indicates the 25th percentile, a line within the box marks the median, and the boundary of the box farthest from zero indicates the 75th percentile. Whiskers (error bars) above and below the box indicate the 90th and 10th percentiles, respectively. Similar letters indicate differences that are not statistically significant between thermal treatments. Control is haemolymph free.

Representación de los datos de actividad de tirosinasa feniloxidasa (PO) bajo diferentes tratamiento térmicos. El límite de la caja cercana a cero indica el percentil 25 , la línea dentro de la caja marca la mediana y los límites de la caja alejada de cero marcan el percentil 25. Las barras de error sobre y bajo la caja indican los percentiles 90 y 10. Las letras similares indican diferencias que no son estadísticamente diferentes entre los tratamientos térmicos. El control es sin hemolinfa.

shifts in the geographical distribution of hostpathogen interactions (Demas \& Nelson 2011). The ecological effects of climate change have been mainly correlative, rather than focused on the primary mechanisms responsible for the observed patterns. Consequently, there is a need for ecological and evolutionary physiology studies to approach this important problem and characterize the biological processes behind these changes (Somero 2005, 2011, Helmuth et al. 2005, Denny \& Helmuth 2009, Bozinovic et al. 2011b, Spicer \& Gaston 1999, Huey et al. 2009).

The expected increasing in the frequency of extreme environmental conditions should have an even greater impact on interactions within ecological communities than the increase in average temperatures. However, 
the discussion, predictions and studies of the effects of climate change on host-pathogen interactions has fundamentally focused on the possible range expansion of diseases owing to a gradual increase in mean temperatures (Seppälä \& Jokela 2010). For example, on the pathogenic interaction of fungi-locust that represents an attractive alternative to chemical pesticide in the control of locusts and, the effectiveness of fungi in killing the host is variable and depends both on environmental temperature and internal physiological state (Catalan et al. 2012). In short, the infectivity of the pathogens and their speed of killing can vary greatly due to changes in mean and variance of environmental temperature and host immunological physiology.

Most insect immune responses are believed to result from the coordination between components of the humoral and the cellular immune systems. The first is manifest largely as soluble proteins and peptides that respond to non-self either by neutralizing it via toxic effects, or by signalling its presence in the haemocoel. The cellular response consists of reservoirs of the soluble humoral components which are released upon contact with suitable signals and cells that respond to non-self by undergoing morphological and behavioural change and encapsulating the immunogenic substrate (Gillespie et al. 1997, Lavine \& Strand 2002). In short, the cells attach to the surface of the immunogen and flatten out, thereby slowly covering its surface with a layer of self tissue, which is melanized This process effectively externalizes the pathogen: the process of melanisation is controlled by the enzyme phenoloxidase and produces cytotoxic products which may of themselves kill the pathogen, but which also provide structural integrity to the encapsulation cells (Siva-Jothy \& Thompson 2002).

Previous results indicate that immune response of insects is affected by environmental temperature (Ouedraogo et al. 2003, Zibaee et al. 2009, Rolff \& Reynolds 2009, Adamo \& Lovett 2011). Particularly, the constitutive immune response seems to be highly sensitive to thermal conditions, being higher at elevated temperatures (Catalán et al. 2012). From now it seems clear that not only average temperatures are important on host-parasite interaction, but also its variation. Consistently with studies on amphibians (Raffel et al. 2006,) and fish (Hori et al. 2012) we observed that antibacterial activity was higher under a constant temperature regimen, contrarily to expect if we consider that under variable temperatures, insects were exposed to higher daily temperatures than those at constant regimen. Then, we hypothesized that a stress associated mechanism may affect negatively the constitutive immune activity in T. molitor (Adamo \& Parsons 2006).

Some hypotheses have been proposed about the link between stress response and immune function and they point principally to how energy and resources are assigned to the different processes in order to maintain the organism functionality. One common hypothesis ("energy crisis" hypothesis) proposes that stress-induced immunosuppression allows animals to assign more energy to flight or fight behavior (Råberg et al. 1998, Segestrom 2007) due to that immune response is expensive. But, since physiological processes are not only limited by energy but by specific molecules too, the "resource crunch" hypothesis suggests that some of these changes will result in resources being shifted away from the immune system in order to optimize the flight-or-fight response (Wingfield 2003, Charmandari et al. 2005). Also, in larval dragonflies and butterflies reduced their immune function after reproductive activity and/or mating behavior in males. These results suggest the existence of engagements between the reproductive potential physiological and immune responsiveness in insects and the high energy cost of this response (Schmid-Hempel 2011).

But what stress mechanism could explain a depletion of immune activity under variable thermal conditions? Immune response and stress have a convergent mechanism. During a stress response, at least two important neurohormones are released: octopamine and adipokinetic hormone. The first is released not only under a stress conditions, but too under an immune challenge (Orchard et al. 1993). It is well known that octopamine increases hemocytes mobility in G. mellonella (Diehl-Jones et al. 1996) which could enhance immune response, but the addition of heatkilled bacteria decreased the hemocytes number (Adamo 2010). Even that, we measured 
constitutive immune response without an immune challenge, then we proposed that the mechanism under the observed pattern where a higher thermal stress induce an immunosuppressive response is more related with the action of octopamine on lysozyme-like activity. The simplest mechanism proposed by Adamo (2010) is that hemocytes become less likely to release lysozyme-like enzymes. In these sense, octopamine and adipokinetic hormone induce lipid released (Orchard et al. 1993, Woodring et al. 1989), and the increase in lipid transport leads to a decline in immune surveillance, resulting in decreased disease resistance (Adamo et al. 2008). In insects, the protein apolipophorin III (apoLpIII) combines with a high density lipoprotein to form a low density lipophorin (Weers \& Ryan 2006) to carry large amounts of lipid liberated from fat body, in order to cope with necessities of energy (Zera et al. 1999). However, the monomeric form apoLpIII also has immunological functions recognizing pathogen molecules as LPS, lipoteichoic acid and bacterial surfaces (Halwani et al. 2000), as well as to 1,3-glucans and fungal conidia (Whitten et al. 2004). After bound to pathogens or its components, apoLpIII, promotes cellular immune reaction such as phagocytosis (Wiesner et al. 1997) and an increase in antibacterial activity in the haemolymph (Wiesner et al. 1997, Dettloff et al. 2001). But, when octopamine and adipokinetic hormone induce lipid released from fat body in insects, apoLpIII shift its function toward lipid transport (Weers \& Ryan 2006) affecting negatively to immune traits like antibacterial activity. Even that, is important to take account that acute stress can results in a mix of immunosuppressive and immunoenhancing effects (Dhabhar 2002, Ortega 2003, Glaser \& Kiecolt-Glaser 2005, Nance \& Sanders 2007, Ortega et al. 2007) in order to maintain the immune homeostasis under diverse situations of stress (Adamo 2008).

Finally the availability of a diversity of immune defense options should increase an organism's survival in front of a variable thermal climate. Alternative defenses may occur at several different levels such a, behavioral avoidance of parasites, barriers that minimize invasion rates of parasites, molecular mechanisms of defense - e.g. alteration of cell surface molecules and/or the delayed adaptive immune response, and immunological tolerance. Thus, future studies should attempt to test how basal immunological traits, defences and its cost are affected by high levels of climatic variability encountered over different habitats and conditions in a global climate scenario (Schmid-Hempel 2011). It is also important to understand in future studies the context of complex life cycles and thus highlight the evolutionary significance of these effects and trade-offs (e.g. Krams et al. 2013). For instance, may or may not these immunological responses be passed on to the next stage in the life cycle? What would be the consequences on Darwinian fitness?

ACKNOWLEDGEMENTS: Authors are supported by grants from Fondo Nacional de Ciencia y Tecnología (FONDECYT) No. 1130051, and Millennium Institute on Immunology and Immunotherapy and Fundación Ciencia Translacional (P09-016-F). Two anonymous referees provided valuable comments.

\section{LITERATURE CITED}

ADAMO SA \& MN PARSONS (2006) The emergency life-history stage and immunity in the cricket, Gryllus texensis. Animal Behaviour 72: 235-244.

ADAMO SA (2008) Norepinephrine and octopamine: linking stress and immune function across phyla. Invertebrate Survival Journal 5: 12-19.

ADAMO SA, JL ROBERTS, RH EASY\& NW ROSS (2008) Competition between immune function and lipid transport for the protein apolipophorin III leads to stress-induced immunosuppression in crickets. The Journal of Experimental Biology 211: 531-538.

ADAMO SA (2010) Why should an immune response activate the stress response? Insights from the insects (the cricket Gryllus texensis). Brain, Behavior, and Immunity 24: 194-200.

ADAMO SA \& MME LOVETT (2011) Some like it hot: the effects of climate change on reproduction, immune function and disease resistance in the cricket Gryllus texensis. The Journal of Experimental Biology 214: 1997-2004.

ARIAS MB, MJ POUPIN \& MA LARDIES (2011) Plasticity of life-cycle, physiological thermal traits and $H s p 70$ gene expression in an insect along the ontogeny: effect of temperature variability. Journal of Thermal Biology 36: 355-362.

ANGILLETTA MJ (2009) Thermal adaptation. A theoretical and empirical synthesis. Oxford University Press, Oxford.

BOZINOVIC F, DA BASTÍAS, F BOHER, S CLAVIJOBAQUET, SA ESTAY \& MJ ANGILLETTA (2011a) The mean and variance of environmental temperature interact to determine physiological tolerance and fitness. Physiological and Biochemical Zoology 84: 543-552. 
BOZINOVIC F, P CALOSI \& JI SPICER (2011b). Physiological correlates of geographic range in animals. Annual Review of Ecology, Evolution, and Systematics 42: 155-179.

BOZINOVIC F, TP CATALÁN, SA ESTAY \& P SABAT (2013) Acclimation to daily thermal variability drives the metabolic performance curve. Evolutionary Ecology Research 15: 579-587

BURROUGHS WJ (2007) Climate change. A multidisciplinary approach. Cambridge University Press, Cambridge.

CATALÁN TP, A WOZNIAK, HM NIEMEYER, AM KALERGIS \& F BOZINOVIC (2012) Interplay between thermal and immune ecology: Effect of environmental temperature on insect immune response and energetic costs after an immune challenge. Journal of Insect Physiology 58: 310317.

CATALÁN TP, M BARCELÓ , HM NIEMEYER, AM KALERGIS \& F BOZINOVIC (2011) Pathogenand diet-dependent foraging, nutritional and immune ecology in mealworms. Evolutionary Ecology Research 13: 711-723.

CHARMANDARI E, C TSIGOS \& G CHROUSOS (2005) Endocrinology of the stress response. Annual Review of Physiology 67: 259-284.

CHECKLEY W, LD EPSTEIN, RH GILMAN, MD FIGUEROA, RI CAMA, JPATZ \& BLACK (2000) Effects of El Niño and ambient temperature on hospital admissions for diarrhoeal diseases in Peruvian children. The Lancet 355: 442-450.

DALLWITZ R (1984) The influence of constant and fluctuating temperatures on development rate and survival of pupae of the Australian sheep blowfly Lucilia cuprine. Entomologia Experimentalis et Applicatta 36: 89-95

DEMAS GE \& RJ NELSON (2011) Ecoimmunology. Oxford University Press, Oxford.

DHABHAR F (2002) Stress-induced augmentation of immune function-The role of stress hormones, leuckocyte trafficking, and cytokines. Brain, Behavior, and Immunity 16: 785-798.

DETTLOFF M, B KAISER \& W WIESNER (2001) Localization of injected apolipophorin III in vivo-new insights into the immune activation process directed by this protein. Journal of Insect Physiology 47: 789-797.

DENNY M \& B HELMUTH (2009) Confronting the physiological bottleneck: a challenge from ecomechanics. Integrative and Comparative Biology 49: 197-201.

DIEHL-JONES WL, CA MANDATO, G WHENT \& RGH DOWNER (1996) Monoaminergic regulation of hemocyte activity. Journal of Insect Physiology 42: $13-19$

EPSTEIN PR, HF DIAZ, S ELIAS, G GRABHERR, NE GRAHAM, WJM MARTENS, E MOSLEYTHOMPSON \& J SUSSKIND (1998) Biological and physical signs of climate change: focus on mosquito-borne diseases. Bulletin of the American Meteorological Society 79: 409-417.

FOLGUERA G, DA BASTÍAS \& F BOZINOVIC (2009) Impact of experimental thermal amplitude on ectotherm performance: adaptation to climate change variability?. Comparative Biochemistry and Physiology Part A: Molecular and Integrative Physiology 154: 389-393.

FOLGUERA G, DA BASTÍAS, J CAERS, JM ROJAS, MD PIULACHS, X BELLÉS \& $F$ BOZINOVIC (2011) An experimental test of the role of environmental temperature variability on molecular, physiological and life-history traits: implications for global warming. Comparative Biochemistry and Physiology Part A: Molecular and Integrative Physiology 159: 242-246

FUTUYMA DJ (2005) Evolution. Sinauer Associates Inc., Massachusetts, USA.

GILLESPIE JP, MR KANOST \& T TRENCZEK (1997) Biological mediators of insect immunity. Annual Review of Entomology 42: 611-643.

GLASER R \& JK KIECOLT-GLASER (2005) Stressinduced immune dysfunction: implications for health. Nature Reviews Immunology 5: 243-251.

HELMUTH B, JG KINGSOLVER \& L CARRINGTON (2005) Biophysics, physiological ecology and climate change: does mechanism matter?. Annual Review of Physiology 67: 177-201.

HALWANI AE, DF NIVEN \& GB DUNPHY (2000) Apolipophorin III and the interactions of lipoteichoic acids with the immediate immune responses of Galleria mellonella. Journal of Invertebrate Pathology 76: 233-241.

HERCUS M, V LOESCHCKE \& SIS RATTAN (2003). Lifespan extension of Drosophila melanogaster through hormesis by repeated mild heat stress. Biogeorontology 4: 149-156.

HILBECK A \& GG KENNEDY (1998) Effect of temperature on survival and preimaginal development rates of Colorado potato beetle on potato and horse-nettle: potential role in host range expansion. Entomologia Experimentalis et Applicatta 89: 261-269.

HORI TS,AK GAMPERL, M BOOMAN, GW NASH \& ML RISE (2012) A moderate increase in ambient temperature modulates the Atlantic cod (Gadus morhua) spleen transcriptome response to intraperitoneal viral mimic injection. BMC Genomics 13: 431-476.

HUEY RB, CA DEUTSCH, JJ TEWKSBURY, LJ VITT, HERTZ, P.E., et al. (2009) Why tropical forest lizards are vulnerable to climate warming. Proceedings of the Royal Society of London B 276: 1939-1948.

JI X, J GAO \& J HAN (2007) Phenotypic responses of hatchlings to constant versus fluctuating incubation temperatures in the multi-banded krait, Bungarus multicintus (Elapidae). Zoological Science 24: 384-390.

KRAMS I, J DAUKSTE, I KIVLENIECE, T KRAMA \& MJ RANTALA (2011) Overwintering survival depends on immune defence and body length in male Aquarius najas water striders. Entomologia Experimentalis et Applicatta 140: 45-51

KRAMS I, J DAUKSTE, I KIVLENIECE, A KAASIK, T KRAMA, TM FREEBERG \& MJ RANTALA (2013) Trade-off between cellular immunity and life span in mealworm beetles Tenebrio molitor. Current Zoology 59: 340-346.

LAMB KP (1961) Some effects of fluctuating temperatures on metabolism, development and rate of population growth in the cabbage aphid, Brevicoryne brassicae. Ecology 42: 740-745.

LAVINE MD \& MR STRAND (2002) Insect hemocytes and their role in immunity. Molecular Biology of Insects 32: 1295-1309.

LEAN JL \& DH RIND (2008) How natural and anthropogenic influences alter global and regional surface temperatures: 1889 to 2006. Geophysical Research Letters 35: 1-6. 
MANDRIOLI M (2012) Someone like it hot? Effects of global warming on insect immunity and microbiota. Invertebrate Survival Journal 9: 58-63.

MIN KJ, MF HOGAN, M TATAR \& DM O’BRIAN (2006) Resource allocation to reproduction and soma in Drosophila: a stable isotope analysis of carbon from dietary sugar. Journal of Insect Physiology 52: 763-70.

MORALES-RAMOS JA, MG ROJAS, DI SHAPIRO-ILAN \& WL TEDDERS (2010) Developmental plasticity in Tenebrio molitor (Coleoptera: Tenebrionidae): Analysis of instar variation in number and developmental time under different diets. Journal of Entomological Science 45: 75-90.

NANCE DM \&VM SANDERS (2007) Autonomic innervation and regulation of the immune system (1987-2007). Brain, Behavior. and Immunity 21: 736-745.

ORCHARD I, JM RAMIREZ \& AB LANGE (1993) A multifunctional role for octopamine in locust flight. Annual Review of Entomology 38: 227-249.

ORTEGA E (2003) Neuroendocrine mediators in the modulation of phagocytosis by exercise: physiological implications. Exercise Immunology Review 9: 70-93.

ORTEGA E, E GIRALDO, MD HINCHADO, L MARTIN, LL GARCIA \& M DE LA FUENTE (2007) Neuroimmunodulation during exercise: role of catecholamines as 'stress mediator' and/or 'danger signal' for the innate immune response. Neuroimmunodulation 14: 206-212.

OUEDRAOGO RM, M CUSSON, MS GOETTEL \& J BRODEUR (2003) Inhibition of fungal growth in thermoregulating locusts, Locusta migratoria, infected by the fungus Metarhizium anisopliae var acridum. Journal of Invertebrate Pathology 82: 103-109.

PAAIJMANS KP, S BLANFORD, AS BELL, JI BLANFORD, AF READ \& MB THOMAS (2010) Influence of climate on malaria transmission depends on daily temperature variation. Proceedings of the National Academy of Sciences USA 107: 15135-15139

PATZ JA, D CAMPBELL-LENDRUM, T HOLLOWAY \& JA FOLEY (2005). Impact of regional climate change on human health. Nature 438: 310-317.

PÉTAVY G, JR DAVID, V DEBAT, P GIBERT \& B MORETEAU (2004) Specific effects of cycling stressful temperatures upon phenotypic and genetic variability of size traits in Drosophila melanogaster. Evolutionary Ecology Research 6: 873-890.

RAGLAND, GJ \& JG KINGSOLVER (2008) The effect of fluctuating temperatures on ectotherm life-history traits: comparisons among geographic populations of Wyeomyia smithii. Evolutionary Ecology Research 10: 29-44.

RÅBERG L, M GRAHN, D HASSELQUIST \& E SVENSSON (1998) On the adaptive significance of stress-induced immunosuppression. Proceedings of the Royal Society of London B 265: $1637-1641$.

RAFFEL TR, JR ROHR, JM KIESECKERS \& PJ HUDSON (2006) Negative effects of changing temperature on amphibian immunity under field conditions. Functional Ecology 20: 819-828.

RAFFEL TR, JM ROMANSIC, NT HALSTEAD, TA MCMAHON,MD VENESKY \& JR ROHR (2013) Disease and thermal acclimation in a more variable and unpredictable climate. Nature Climate Change 3: 146-151

RAHMSTORF S \& D COUMOU (2011) Increase of extreme events in a warming world. Proceeding of the National Academy of Sciences USA 108: 17905-17909.

ROLFF J \& SE REYNOLDS (2009) Insect infection and immunity: evolution, ecology, and mechanisms. Oxford University Press. Oxford, New York.

ROHR JR, AP DOBSON, PT JOHNSON, AM KILPATRICK, SH PAULL, TR RAFFEL, D RUIZMORENO \& MB THOMAS (2011) Frontiers in climate change-disease research. Trends in Ecology and Evolution 26: 270-277.

SCHNEIDER PM (1985) Purification and properties of three lysozymes from hemolymph of the cricket, Gryllus bimaculatus (De Geer). Insect Biochemistry 15: 463-470.

SCHMID-HEMPEL P (2011) Evolutionary parasitology. The integrated study of infections, immunology, ecology and genetics. Oxford University Press, Oxford.

SEGERSTROM SC (2007) Stress, Energy and Immunity: an ecological view. Current Directions in Psychological Science 16: 326-330.

SEPPÄLÄ O \& J JOKELA (2010) Maintenance of genetic variation in immune defense of a freshwater snail: role of environmental heterogeneity. Evolution 64: 2397-2407.

SIVA-JOTHY MT \& JJW THOMPSON (2002) Shortterm nutrient deprivation affects immune function. Physiological Entomology 27: 206-212.

SIVA-JOTHY MT, Y MORET \& J ROLFF (2005) Insect immunity: An evolutionary ecology perspective. Advances in Insect Physiology 32: 1-48.

SÖDERHÄLL K \& L CERENIUS (1998) Role of the prophenoloxidase-activating system in in vertebrate immunity. Current Opinion in Immunology 10: 23-28.

SOMERO GN (2005) Linking biogeography to physiology: evolutionary and acclimatory adjustments of thermal limits. Frontiers in Zoology 2: 1-9.

SOMERO GN (2011) Comparative physiology: a "crystal ball" for predicting consequences of global change. American Journal of Physiology - Regulatory, Integrative and Comparative Physiology 301: R1-R14.

SPICER JI \& KJ GASTON (1999) Physiological diversity and its ecological implications. Blackwell Science, Oxford.

SUGUMARAN M (2002) Comparative biochemistry of eumelanogenesis and the protective roles of phenoloxidase and melanin in insects. Pigment Cell Research 15: 2-9.

TABACHNICK WJ (2010) Challenges in predicting climate and environmental effects on vector-borne disease episystems in a changing world. Journal of Experimental Biology 213: 946-954.

TERBLANCHE JS, C NYAMUKONIWA \& K ELSJE (2010) Thermal variability alters climatic stress resistance and plastic response in a global invasive pest, The Mediterranean fruit fly (Ceratitis capitata). Entomologia Experimentalis et Applicatta 137: 304-315

URREJOLA S, R NESPOLO \& MA LARDIES (2011) Dietinduced developmental plasticity in life histories and energy metabolism in a beetle. Revista Chilena de Historia Natural 84: 523-533. 
WEERS PMM \& RO RYAN (2006) Apolipophorin III: role model apolipoprotein. Insect Biochemistry and Molecular Biology 36: 231-240.

WHITTEN MMA, IF TEW, BL LEE \& NA RATCLIFFE (2004) A novel role for an insect apolipoprotein (Apolipophorin III) in beta-1,3-glucan pattern recognition and cellular encapsulation reactions. Journal of Immunology 17: 2177-2185.

WIESNER A, S LOSEN, P KOPÁCEK, C WEISE \& P GÖTZ (1997) Isolated apolipophorin III from Galleria mellonella stimulates the immune reactions of this insect. Journal of Insect Physiology 43: 383-391.

WILLIAMS CM, KE MARSHALL, HA MACMILLAN, JDK DZURSIN, JJ HELLMANN \& BJ SINCLAIR (2012) Thermal variability increases the impact of autumnal warming and drives metabolic depression in an overwintering butterfly. Plos One 7: e34470.
WINGFIELD JC (2003) Control of behavioural strategies for capricious environments. Animal Behaviour 66: 807-816.

WOODRING J, LA MCBRIDE \& P FIELDS (1989) The role of octopamine in handling and exerciseinduced hyperglycaemia and hyperlipaemia in Acheta domesticus. Journal of Insect Physiology 35: 613-617.

ZERA AJ, J SALL \& K OTTO (1999) Biochemical aspects of flight and flightlessness in Gryllus: flight fuels, enzyme activities and electrophoretic profiles of flight muscles from flight capable and flightless morphs. Journal of Insect Physiology 45: 275-285.

ZIBAEE A,AR BANDANI, R TALAEI-HASSANLOUEI \& D MALAGOLI (2009) Temperature and $\mathrm{Ca}^{2+}$ ion as modulators in cellular immunity of the Sunn pest Eurygaster integriceps Puton (Heteroptera: Scutelleridae). Entomological Research 39: 364371. 
